\title{
Species of Amauroderma (Ganodermataceae) in Santa Catarina State, Southern Brazil
}

\author{
Marisa Campos-Santana * \\ Clarice Loguercio-Leite
Laboratório de Micologia, Departamento de Botânica, Centro de Ciências Biológicas Universidade Federal de Santa Catarina, CEP 88010-970, Florianópolis - SC, Brazil
*Author for correspondence \\ marisacampossantana@gmail.com
}

Submetido em 25/02/2012

Aceito para publicação em 19/09/2012

\section{Resumo}

Espécies de Amauroderma (Ganodermataceae) no Estado de Santa Catarina, Sul do Brasil. Seis espécies de Amauroderma, A. brasiliense, A. camerarium, A. intermedium, A. omphalodes, A. schomburgkii e A. sprucei ocorrem em Santa Catarina. Chave para identificação e comentários sobre as espécies são apresentados.

Palavras-chave: Mata Atlântica; Micodiversidade; Polyporales

\section{Abstract}

Six species of Amauroderma, A. camerarium, A. brasiliense, A. intermedium, A. omphalodes, $A$. schomburgkii and $A$. sprucei, occur in the Santa Catarina. An identification key and comments about the species are presented.

Key words: Altantic Forest; Mycodiversity; Polyporales

\section{Introduction}

The genus Amauroderma was created by Murrill (1905) with Fomes regulicolor Berk. ex Cooke (=Amauroderma schomburgkii (Mont. \& Berk.) Torrend), from Cuba, as the holotype. Afterwards, Torrend (1920) worked on the genus in South America and, based mainly on spore shape (globose or oblong, never truncate) and the presence of a stipe (usually dull, like the pilear surface), published an important work that recorded 28 species of Amauroderma placed within three sections. Later, Amauroderma was carefully revised by Furtado (1981), who recognized 27 species. Furtado defined Amauroderma by the globose to subglobose basidiospores, with double walls, stipitate basidiomes and a tropical distribution pattern. Ryvarden (2004) described 21 species of Amauroderma from the Neotropics, using the same genus circumscription. However, according to Index Fungorum (2012), there are 85 binomials of this genus. 
Recently, Campacci and Gugliotta (2009) published a bibliographic review on Amauroderma from Brazil, in which 20 species were accepted and 10 taxa were excluded because they belong to other genera or had insufficient data and/or dubious names.

In the state of Santa Catarina there are records of six species of Amauroderma (LOGUERCIO-LEITE et al., 2009; CAMPOS-SANTANA; LOGUERCIO-LEITE, 2010). In the present work, a review of the Amauroderma species from the herbarium FLOR was made to determinate their occurrence in this region. In addition, comments and an identification key are presented.

\section{Materials and Methods}

The study was based on collections of Amauroderma species from Santa Catarina State $\left(26^{\circ}-30^{\circ} \mathrm{S}, 48^{\circ} 30^{\prime}-54^{\circ} \mathrm{W}\right)$. Macroscopic and microscopic data of the specimens were obtained following traditional methodologies (SINGER, 1975; RYVARDEN, 1991) and the colors were determined according to Munsell (1975). All specimens are deposited in the herbarium FLOR at the Universidade Federal de Santa Catarina. Herbarium acronyms are based on Holmgren et al. (1990). Specimens were identified and the geographical distributions were determined using literature about the Ganodermataceae.

\section{Taxonomy}

Amauroderma brasiliense (Singer) Ryvarden Synopsis Fungorum 19: 44, 2004. $\equiv$ Scutiger brasiliensis Singer. Nova Hedwigia, Beih. 17:22, 1983.

Description in Gulaid \& Ryvarden (1998).

Distribution: Neotropical, Brazil and Venezuela (RYVARDEN, 2004). In Brazil cited from the states of Amazônia (holotype), Paraná, Rio Grande do Sul, Rondônia, Santa Catarina and São Paulo (SINGER et al., 1983; GULAID; RYVARDEN, 1998; RYVARDEN; MEIJER, 2002; GROPOSO; LOGUERCIO-LEITE, 2005; MEIJER, 2006; COELHO et al., 2007; CAMPACCI; GUGLIOTTA, 2009).
Comments: The material examined is typical for this species. It is (= Amauroderma corneri Gulaid \& Ryvarden) recognized by its fleshy, fan-shaped basidiomes that are fragile when dry. It is also distinct because of its whitish color when compared with others species of the genus, which are often shades of brown. Further, the generative hyphae are dominant and some skeletal hyphae, which are usually smooth or occasionally tuberculate, show apical swellings (GULAID; RYVARDEN, 1998).

Examined material: BRAZIL, Santa Catarina, Santo Amaro, Parque Estadual Serra do Tabuleiro, Vargem Braço. C. Groposo 110, 28/III/2001 (FLOR 31323).

Amauroderma camerarium (Berk.) J. S. Furtado.

Rev. Gen. Amauroderma: 140, 1968. $\equiv$ Polyporus camerarius Berk. Lond. J. Bot. 8: 143, 1856.

Description in Furtado (1981).

Distribution: Neotropical, Brazil, Belize, Colombia, Cuba, Honduras, Peru and Venezuela (FURTADO, 1981; RYVARDEN, 2004). In Brazil cited from the states of Amazônia (holotype), Bahia, Mato Grosso, Paraná, Pernambuco, Rio de Janeiro, Rio Grande do Sul and Santa Catarina (RICK, 1960; FURTADO, 1981; RAJCHENBERG; MEIJER, 1990; SILVEIRA; GUERREIRO, 1991; GÓES-NETO, 1999; RYVARDEN; MEIJER, 2002; GROPOSO; LOGUERCIO-LEITE, 2005; MEIJER, 2006; CAMPACCI; GUGLIOTTA, 2009).

Comments: Furtado (1981), when examining the holotype (Sprucei 171), pointed out the presence of yellowish basidiospores, a characteristic also found in our specimen; this is a good way to distinguish this species from Amauroderma schomburgkii that has hyaline basidiospores. However, Furtado also reported the larger basidiospores $(10-13 \times 9-11 \mu \mathrm{m})$ compared to the specimen at FLOR $11902([8.8] 9-11 \times[7.5] 8$ $9[10] \mu \mathrm{m})$. The same author stated that the separation between $A$. camerarium and A. omphalodes is even more confusing. Ryvarden (2004) emphasized the presence of dextrinoid skeletal hyphae and the large basidiospores $(12-15[-16] \times 10-13 \mu \mathrm{m})$ as the most distinctive features 
of this species, although this is quite different from what we observed.

Examined materials: BRAZIL, Santa Catarina, Santo Amaro da Imperatriz, Hotel Plaza, Trilha Cascata, Serra do Tabuleiro, Groposo 097, 05/I/2001 (FLOR 11902).

Amauroderma intermedium (Bres. \& Pat.) Torrend.

Brotéria, ser. bot. 18: 128. 1920

$\equiv$ Ganoderma intermedium Bres. \& Pat. Bull. Soc. Mycol Fr. 5:76, 1889.

Description in Ryvarden (2004).

Distribution: Neotropical, Brazil, Guadalupe, Martinique, Paraguay and Puerto Rico (TORREND, 1920; RYVARDEN, 2004). In Brazil cited from the states of Amazônia, Rio de Janeiro, Rio Grande do Sul, Santa Catarina and São Paulo (TORREND, 1920; FURTADO, 1981; LOGUERCIO-LEITE et al., 2009).

Comments: Amauroderma intermedium presents pale-yellowish, finely asperulate, sub-globose basidiospores $(8-11 \times 7-8 \mu \mathrm{m})$. Furtado $(1981)$ regards it as Amauroderma rude var. intermedium. However, Ryvarden (2004) considers A. intermedium an independent taxon. Both authors reported similar basidiospores size and very conspicuous endosporic projections.

Examined materials: BRAZIL, Santa Catarina, Santo Amaro da Imperatriz, Hotel Caldas da Imperatriz, T-Pereira, s/n. 31/III/2007 (FLOR 32197); ibid, ipse, 10/XI/2007 (FLOR 32198).

Amauroderma omphalodes (Berk.) Torrend

Brotéria, ser. bot 18: 131, 1920.

$\equiv$ Polyporus omphalodes Berk. Lond. J. Bot. 8:

$172,1856$.

Description in Furtado (1981).

Distribution: Neotropical, Brazil, Guyana, Venezuela and Colombia (RYVARDEN, 2004). In Brazil cited from the states of Amazônia, Alagoas, Bahia, Rio de Janeiro, Mato Grosso, Paraná, Pernambuco, Sergipe and
Santa Catarina (TORREND, 1920; FURTADO, 1981; RYVARDEN, 1984; LOGUERCIO-LEITE; WRIGHT, 1991; GÓES-NETO, 1999; RYVARDEN; MEIJER, 2002; GIBERTONI et al., 2004; DRECHSLERSANTOS et al., 2008; CAMPACCI; GUGLIOTTA, 2009).

Comments: Furtado (1981) pointed out that this species is very similar to Amauroderma camerarium and $A$. sprucei, mainly because of the light colored context. However, A. camerarium differs in the pilear cover, which is formed by a cortex, and $A$. sprucei can be distinguished by the size $(11-13 \times 9-11 \mu \mathrm{m}$ in $A$. omphalodes and 9-10 $\times 7-8 \mu \mathrm{m}$ in $A$. sprucei) of the basidiospores (FURTADO, 1981).

Examined materials: BRAZIL, Santa Catarina, Florianópolis, Rio Tavares, Furlani 274, 04/VII/1986 (FLOR 10460).

\section{Amauroderma schomburgkii (Mont. \& Berk.)} Torrend

Brotéria, ser. bot. 18:140. 1920.

$\equiv$ Polyporus schomburgkii Mont. \& Berk. Lond. J. Bot. 3:331. 1844

Description in Furtado (1981).

Distribution: Neotropical, Brazil, Colombia, Costa Rica, Cuba, Guiana Francesa, Guiana, Venezuela, Jamaica, Nicarágua, Panamá and Trinidad (TORREND, 1920; CORNER, 1983; RYVARDEN, 2004). In Brazil cited from the states of Amazônia, Bahia, Mato Grosso, Pará, Paraná, Pernambuco, Rio de Janeiro, Rio Grande do Sul, Rondônia, Santa Catarina, Sergipe and São Paulo (TORREND, 1920; FURTADO, 1981; CORNER, 1983; RAJCHENBERG; MEIJER, 1990; GÓIS-NETO, 1999; RYVARDEN; MEIJER, 2002; SOTÃO et al., 2002; GIBERTONI et al., 2004; MEIJER, 2006; CAMPACCI; GUGLIOTTA, 2009; CAMPOSSANTANA; LOGUERCIO-LEITE, 2010).

Comments: This species is characterized by its small pores $(5-7 / \mathrm{mm})$, the globose basidiospores that are 7 $-9(-11) \times 7-9 \mu \mathrm{m}$, and the yellowish to citric yellow arboriform skeletal hyphae that are $5-8(-10) \mu \mathrm{m}$ wide. According to Furtado (1981), this species is the most 
common of the genus in the Neotropics. The specimen FLOR 31344 was found growing on roots on soil. There are other examples of Amauroderma species growing on the soil, such as A. coltricioides T. W. Henkel, Aime $\&$ Ryvarden recorded by Silveira et al. (2008) and $A$. calcigenum (Berk.) Torrend recorded by Gomes-Silva et al. (2010).

Examined materials: Brazil, Santa Catarina, Herciliopólis, Água Doce, Folle \& Willerding 046, 23/ VIII/1992 (FLOR 11104); ipse, ibid, 047 (FLOR 11105); Ilhota, Morro Baú, C. Groposo s/n, /VII/2003 (FLOR 31344); Alfredo Wagner, Rio das Furnas, A. Gerlach \& Giovanka 136, 07/VII/2008 (FLOR 32345).

\section{Amauroderma sprucei (Pat.) Torrend}

Brotéria ser. bot. 18: 121, 1920.

$\equiv$ Ganoderma sprucei Pat. Bull. Soc. Mycol. Fr.

$$
\text { 10:75, } 1894 .
$$

Description in Decock \& Herrera Figueroa (2006) [stricto sensu].

Distribution: Neotropical, Brazil, Costa Rica, Colombia, Cuba, Puerto Rico, Jamaica, Belize, French Guiana and Venezuela (RYVARDEN, 2004; CAMPACCI; GUGLIOTTA, 2009). In Brazil cited from the states of Amazônia, Minas Gerais, Mato Grosso, Pará, Paraná, Pernambuco, Rio de Janeiro, Rio Grande do Sul, Santa Catarina, São Paulo and Sergipe (RICK, 1960; TORREND, 1920; FURTADO, 1981; CORNER, 1983; RAJCHENBERG; MEIJER, 1990; RYVARDEN; MEIJER, 2002; RYVARDEN, 2004; GIBERTONI et al., 2004; DECOCK; HERRERA FIGUEROA, 2006).

Comments: This species is characterized by a stipitate to occasionally subsessile basidiome, a dull brown (chocolate brown) pileus, a reddish yellow pore surface, small pores (7-8/mm) and a whitish context (DECOCK; HERRERA FIGUEROA, 2006). Previously, Ryvarden (2004) considered A. sprucei as an independent taxon from A. dubiopansum because of its brilliant pore surface and the strong dextrinoid reaction on skeletal hyphae.

Examined material: BRAZIL, Santa Catarina, Mondaí,
Linha Uruguai, M. Campos-Santana 190, 27/XII/2006 (FLOR 32210).

\section{Key to Amauroderma in Santa Catarina State}

1 Pores 1-4 per mm .................................................. 2

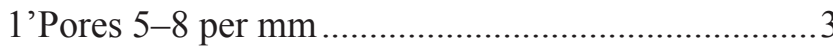

2 Pores $1-2$ per mm, basidiospores globose, $6.5-8.5 \mu \mathrm{m}$ in diameter, hyaline to pale yellow A. brasiliense

2'Pores 2-4 per mm, basidiospores sub-globose, 8-11 $\times 7-8 \mu \mathrm{m}$, yellowish A. intermedium

3 Pore surface reddish yellow, skeletal hyphae dextrinoid A. sprucei

3'Pore surface differently colored, skeletal hyphae not dextrinoid 4

4 Skeletal hyphae arboriform yellowish to citric yellow, basidiospores globose, hyaline............A. schomburgkii

4'Skeletal hyphae arboriform hyaline, basidiospores sub-globose to broadly ellipsoid, yellowish 5

5 Pileus surface yellowish brown to pale grayish brown, context first white then cream coloured .... A. camerarium 5'Pileus surface reddish brown, context yellowish brown to cinnamon A. omphalodes

\section{References}

CAMPACCI, T. V. S.; GUGLIOTTA, A. M. A review of Amauroderma in Brazil, with A. oblongisporum newly recorded from the neotropics. Mycotaxon, Ithaca, n. 110, p. 423-436, 2009.

CAMPOS-SANTANA, M.; LOGUERCIO-LEITE, C. AustroAmerican lignocellulolytic basidiomycetes (Agaricomycotina): new records. Mycotaxon, Ithaca, n. 114, p. 377-393, 2010.

COElHO, G.; CORTEZ, V. G.; GUERRERO, R. T. New morphological data on Amauroderma brasiliense (Polyporales, Basidiomycota). Mycotaxon, Ithaca, n. 100, p. 177-183, 2007.

CORNER, E. J. H. Ad. Polyporaceae I. Beih. Zur. Nova Hedwigia, Stuttgart, v. 75, p. 5-182, 1983.

DECOCK, C.; HERRERA FIGUEROA, S. Neotropical Ganodermataceae (Basidiomycota): Amauroderma sprucei and $A$. dubiopansum. Cryptogamie Mycologie, Paris, v. 27, n. 1, p. 3-10, 2006.

DRECHSLER-SANTOS, E. R.; GROPOSO, C.; LOGUERCIOLEITE, C. Additions to the knowledge of lignocellulolytic basidiomycetes in forests from Santa Catarina, Southern Brazil. Mycotaxon, Ithaca, n. 103, p. 197-200, 2008. 
FURTADO, J S. 1981. Taxonomy of Amauroderma (Basidiomycetes, Polyporaceae). New York: Memoirs New York Botanical Garden 34, 1981. 104 p.

GÓES-NETO, A. Polypore diversity in the State of Bahia, Brazil: a historical review. Mycotaxon, Ithaca, n. 72, p. 43-56, 1999.

GOMES-SILVA, A. C.; BALTAZAR, J. M.; RYVARDEN, L.; GIBERTONI, T. B. Amauroderma calcigenum (Ganodermataceae, Basidiomycota) and its presumed synonym A. partitum. Nova Hedwigia, Stuttgart, v. 90, n. 3-4, p. 449-455, 2010.

GIBERTONI, T. B.; RYVARDEN, L.; CAVALCANTI, M. A Q. Poroid fungi (Basidiomycota) of the Atlantic Rain Forest in Northeast Brazil. Synopsis Fungorum, Oslo, n. 18, p. 33-43, 2004 GROPOSO, C.; LOGUERCIO-LEITE, C. Contribution to the lignocellulolytic fungi (Basidiomycetes) of the Atlantic Rain Forest in Southern Brazil. Mycotaxon, Ithala, n. 92, p. 103-106, 2005.

GULAID, H.; RYVARDEN, L. Two new species of Amauroderma (Ganodermataceae, Basidiomycetes). Mycologia Helvetica, Bussigny, v. 10, n. 1, p. 25-30, 1998.

HOLMGREN, P. K.; HOLMGREN, N. H.; BARNETT, L. C. Index Herbariorum. Part 1. The Herbaria of the World. New York: International Association for Plant Taxonomy, Botanical Garden, $1990.693 \mathrm{p}$.

INDEX FUNGORUM. Cabi Bioscience Databases Amauroderma. 2012. Disponível em $<$ http://www.indexfungorum. org/names/Names.asp>. Acesso em: 12 janeiro 2012.

LOGUERCIO-LEITE, C.; CAMPOS-SANTANA, M.; GERLACH, A.; GUTJAHR, M.; TRIERVEILER-PEREIRA, L.; DRECHSLERSANTOS, E. R.; BALTAZAR, J. M. Résumé of macromycetes from Santa Catarina State, Southern Brazil. Insula, Florianópolis, n. 38 , p. $1-14,2009$.

LOGUERCIO-LEITE, C.; WRIGHT, J. E. Contribution to a biogeographical study of the Austroamerican xylophilous polypores (Aphyllophorales) from Santa Catarina Island, SC, Brazil. Mycotaxon, Ithala, n. 41, p. 161-166, 1991.

MEIJER, A. A. R. Preliminary list of macromycetes from the Brazilian State of Paraná. Boletim do Museu Botânico Municipal Curitiba, n. 68, p. 1-55, 2006.
MUNSELL, L. Munsell soil color charts. New Windsor: United States Department of Agriculture Hand. 18. Soil Survey Manual, 1975. $32 \mathrm{p}$.

RAJCHENBERG, M.; MEIJER, A. A. R. New and noteworthy polypores from Paraná and São Paulo States, Brazil. Mycotaxon, Ithala, n. 38, p. 173-185, 1990.

RICK, J. Basidiomycetes Eubasisii in Rio Grande do Sul, Brasília 4. Meruliaceae, Polyporaceae, Boletaceae. Iheringia, Série Botânica, Porto Alegre, v. 7, p. 193-295, 1960.

RYVARDEN, L. Type studies in the Polyporaceae 16. Species described by J.M. Berkeley, either alone or with other mycologists, from 1856 to 1886. Mycotaxon, Ithala, n. 20, p. 329-363, 1984.

RYVARDEN, L. Genera of Polypores - Nomenclature and taxonomy. Oslo: Synopsis Fungorum 5, 1991. 363 p.

RYVARDEN, L. Neotropical polypores. Part 1. Oslo: Synopsis Fungorum 19, 2004. 230 p.

RYVARDEN, L.; MEIJER, A. A. R. Studies in Neotropical polypores 14 - new species from the state of Parana, Brazil. Synopsis Fungorum, Oslo, n. 15, p. 34-69, 2002.

SILVEIRA, R. M. B.; GUERRERO, R. T. Aphyllophorales poliporóides (Basidiomycetes) do Parque Nacional de Aparados da Serra, Rio Grande do Sul. Boletim do Instituto de Biociências, Porto Alegre, v. 48, p. 1-127, 1991.

SILVEIRA, R. M. B.; RECK, M. A.; GRAF, L. V.; SÁ, F. N. Polypores from a Brazilian pine forest in Southern Brazil: pileate species Hoehnea, São Paulo, v. 35, n. 4, p. 619-630, 2008.

SINGER, R. 1975. The Agaricales (Mushrooms) in Modern Taxonomy. 3 ed. Vaduz: Cramer, 1975. 832 p.

SINGER, R.; ARAUJO, I.; IVORY, M. H. The ectotrophic mycorrhizal fungi of the Neotropical Lowlands, especially Central Amazonia. Beih. Zur. Nova Hedwigia, Stuttgart, v. 77, p. 1-352, 1983.

SOTÃO, H. M. P.; GUGliOtTA, A. M.; OliVEIRA, A. P.; LUZ, A. B.; MELO, O. A. Fungos poliporóides. In: LISBOA, P. L. B. (Org.). Caxiuanã. Populações tradicionais, meio físico e diversidade biológica. Belém: Museu Paraense Emílio Goeldi, 2002. p. 433-444.

TORREND, C. Les Polyporacées du Brésil. Brotéria, Lisboa, v. 18, p. 121-143, 1920. 